\title{
Coronavirus Legislation and Obligations of Lessee in Jordan: Some Preliminary Reflections/Considerations
}

\author{
Mohammed Ibrahim Abu El-Haija ${ }^{1}$ (i)
}

Accepted: 3 April 2021 / Published online: 13 April 2021

(c) The Author(s), under exclusive licence to Springer Nature B.V. 2021

\begin{abstract}
This study focuses on discussing the choices of lessee in Jordan legislation because of a Defense Order in Curfew to face Corona Virus Disease 2019 and the impact of Corona virus disease 2019 (COVID-19) on the lessor obligation. The study finds out that the lessee has two options: to cancel the contract regarding force majeure or refuge to court and to reduce the fare amount regarding exceptional circumstances. The study also recommended issuing a Defense Order specifying the exact percentage to be reduced. In the absence of a Defense Order, the study of a friendly agreement should be recommended between the lessor and the tenant on the reduced percentage.
\end{abstract}

Keywords COVID-19 $\cdot$ Defense order $\cdot$ Defense law $\cdot$ Leasing contract

\section{Introduction}

On December 2019, Corona Virus 19 (COVID-19) became widespread all across the whole world. The International Health Organization announced on March 2020 that COVID-19 is considered as an international epidemic and needs international efforts and cooperation to resist it.

On March 18, 2020, Jordan began to apply national defense law regarding Royal Decree. This law gives power to the council of ministry to suspend any of the ordinary laws of the state and issue new laws. The defense order number 2 was closedown from March 17, 2020, till May 31, 2020.

The main question here is: what is the impact of defense order number two "closedown" on real-estate obligation? Does the tenant's obligation in monthly fare mean suspension also or not?

Furthermore, the study provided answers to the above question regarding Jordan laws and cassation court decisions.

Mohammed Ibrahim Abu El-Haija

mohammedhaija@yahoo.com

1 Middle East University, Amman, Jordan 


\section{A Glance of Jordan Defense Law}

The Defense Law was put in place to face any emergency cases such as war, natural disasters, armed security or public safety, and epidemic. It has the power to suspend any ordinary laws by the council of ministry so as to face these emergences.

Jordan's constitution ${ }^{1}$ enacted on defense law in article number 124 states that "In the event of what necessitates the defense of country in the case of emergencies, a law in the name of the Defense Law shall be enacted by virtue of which power shall be given to the person specified by the law to take the necessary actions and measures including the power of suspension of the ordinary laws of the state to ensure the defense of the country. The defense law shall come into force and this is declared by Royal Decree to be issued on the basis of a decision by the Council of Ministries."

Regarding article 124 of the Jordan constitution, the defense law $^{2}$ was issued. This is where article number 2 explains its objectives. It stipulates that "Upon a decision and a Royal Decree, a National Defense Law shall be passed in case of emergency that would threaten the national security or public safety in all parts of the kingdom or in a region due to war, disturbances, armed internal strife, public disasters or the spread of a pest or epidemic." While the third article of the law states that "A-The application of this law shall be entrusted to the Prime Minister to take the necessary measures and procedures so as to ensure public safety and defend the kingdom without being bound by the provisions of regular laws in force. B-The Prime Minister exercises his powers according to written orders. C-The Prime Minister may delegate all or some of his powers to whomever he deems fit to do so throughout the kingdom or in a specific region thereof, subject to conditions and restrictions that he appoints." The Powers of the Prime Minister mentioned in article 4 states that "The Prime Minister may exercise the following powers: (A) Placing restrictions on the freedom of people to gather, move, reside, and arrest or detain suspects or those who pose a threat to the national security and public order. (B) Assigning any person to perform any work or service within their ability. (C) Checking persons, places and vehicles without being bound by the provisions of any order of law, and ordering the use of appropriate force in the event of opposition. (D) Setting possession of movable and immovable property and postponing debt payment and the accrued liability. (E) Preventing or restricting the importation, exportation or transfer of goods from one place to another and prohibiting their concealment, destruction, purchase or bartering them, and setting their prices. (F) Seizing any land, building, road, or source of water and energy, removing any trees or installations on them, establishing facilities for defense purposes instead and ordering the concerned parties to manage, exploit and organize their use. (G) Evacuating or isolating some areas and imposing curfew on them. $(\mathrm{H})$ Ordering some or all public stores to open and close at a specific time. (I) Regulating and specifying transportation between different regions, blocking any roads or water stream or changing its direction and preventing traffic or regulating it. (J) Monitoring messages, newspapers, publications, pamphlets,

\footnotetext{
1 Constitution of 1952 amended in the year 2011.

2 The Defense Law Number 13 in the year 1992.
} 
drawings, and all means of expression, publicity and advertisement before they are published and seizing, confiscating, suspending, and closing the places where they were prepared. (K) Preventing taking pictures or making designs or maps for any specific place or thing that might benefit the enemy, preventing having any photographic equipment or materials for making photos, designs or maps in such places, and preventing staying for so long in those places without a legitimate excuse. (L) Cancelling licenses of firearms, ammunition, explosives, or explosive materials that are used in the manufacture of explosives, preventing their manufacture, sale, purchase, transfer, disposing them, ordering their delivery and seizure, and closing the shops where they are sold or stored. (M) Preventing the manufacture, sale, purchase or possession of telecommunication equipment and ordering their delivery and seizure."

\section{Order Defense in Jordan}

Till Jan 6, regarding Defense law, the Prime Minister issued 24 orders. Some of these orders are related to labor law, while others relate to social security law, Curfew, and Punishments. For instance, the order number 1 suspended some provisions on social Security Law, while order number 2 declared Curfew in all regions of the kingdom from 7 am with all stores closed. In order number $3,{ }^{3}$ punishment on violating order number 2 was issued. The penalties included a fine from JD 100 and not more than JD 500, imprisonment for a period not exceeding one year, and seizure of vehicles used during the curfew.

\section{Discussion}

\subsection{The Impact of Curfew on Tenant Obligation in Lease Payment}

The prohibition of the operation of commercial enterprises, educational institutions, restaurants and the possible expected curfew are necessary measures in the fight against COVID-19. However, COVID-19 pandemic and the measures adopted to contain it also represent a major challenge for the entire population in terms of their

\footnotetext{
3 It was issued on March 26, 2020, where it enacts laws in accordance with the provisions of article 3 and 7 of Defense Law No. 13 of 1992. Thereafter, with Defense Order No. 2 dated March 20, 2020, the decision was made to issue the following defense order: (1) A fine of not less than JD 100 and not more than JD 500 will be levied if the violation occurs for the first time. Prosecution will not take place if the violator pays the minimum amount of the fine within a week from the date of violation. (2) Imprisonment for a period that does not exceed one year or a fine of not less than JD 100 and not more than JD 500 , or both penalties in the event of repetition. 3. Any vehicle used during the curfew will be seized for a period of 30 days.

Second: Those who open shops with permits outside of the approved hours shall be punished with a fine of not less than JD 1.000 and the shop will be closed for a period of 14 days.

Third: Those who open shops without a permit shall be punished with detention for a period that does not exceed three months or a fine of JD 3.000, or both penalties.
} 
economic consequences. The pandemic threatens, in addition to health, landlords and tenants. In dealing with the pandemic and its consequences, several legal questions arise, the answers to which are not always easy in view of the novelty of the facts and which also cause a certain amount of uncertainty among market participants. Much is in flux as legislators and government are trying to mitigate the economic consequences for market participants with a variety of measures, including legislative measures. Among the questions regularly raised in the course of dealing with the consequences of the pandemic are those relating to tenancy law.

Residential tenants ask themselves what will happen if, due to the economic consequences of the pandemic, they are no longer able to pay their rent on time, for example because of reduced pay due to short-time work, loss of income for the self-employed or even unemployment. Commercial tenants are faced with a situation in which they could, in principle, continue to use the rented property, but such use makes little business sense-or even orders to prohibit or close down operations. Some commercial tenants are also subject—at least according to the wording of the lease agreement - to a duty to operate, which in principle obliges them to maintain operations.

Landlords have calculated with regular rental income and may make their living from it, have based their profitability calculations, liquidity planning and financing on regularly recurring rental income, see themselves exposed to payment obligations to third parties and ask themselves how they can deal with large-scale loss of rental income in the event of economic difficulties.

The following article attempts to provide a brief overview of the current and possible future legal conditions and opportunities for tenants and landlords-with a focus on commercial leases and an attempt to take into account recent developments in a dynamic environment. The below information is intended to provide a general overview of the legislative developments, in light of the coronavirus (COVID-19) outbreak, in the Hashemite Kingdom of Jordan (Jordan). The information included in this report represents the current situation as of the date hereof. Governmental decisions and announcements are continuously being published, legislation updated and the situation evolving as the world manoeuvres through these unprecedented times.

Regarding Defense Order No. 2 Curfew in all regions of the kingdom from $7 \mathrm{am}$ with all stores closed, all stores were closed for four days. Thereafter, another order was made which permitted specific shops to open between $10 \mathrm{am}$ and $6 \mathrm{pm}$ to allow citizens to secure their basic food supplies such as: grocery, minimarket, bakeries, pharmacies, and others who are supplying product. However, some other shops, offices, and clinics were excluded from opening. Much later, the Defense Orders permitted some shops to open gradually. Nonetheless, some other shops still remained closed.

Thus, this poses a few questions: Is the latent obliged to pay the fare to the landholder or is it suspended also? Or does the latent have the right to cancel the contract? Or is there a need to apply court decision? To answer these questions, this study shall distinguish between force majeure and exceptional circumstances. 
The Jordan legislator which defines leasing ${ }^{4}$ contract in article No. 568 of Civil Code No. 43 in the year 1976 states that "A hire shall be the conferring by the lessor on the lease of the right of use intended for the thing hired for a specified period in consideration of an ascertained rent." Therefore, the lessor obligation of the fare continues within the contract period.

Article No. 11 of Defense Law states that "If any contract or obligation cannot be executed due to the observance of the provisions of this Law or any order or instructions issued under it or because of the transfer of these provisions, the person associated with this contract shall not be considered to be in violation of his terms, but the contract shall be considered suspended to the extent that the execution of the contract is impossible." This is considered as a defense in any proceeding sought or initiated against him or any actions taken against him as a result of his failure to implement the contract or obligation. Regarding this article, is suspended period considered a force majeure or exceptional circumstances? Suspended period means that shops closedown and are observing curfew.

The Force majeure was defined in the article No. 247 of Civil Code which states that "In contracts biding on both parties, if force majeure supervene which makes the performance of the contract impossible, the corresponding obligation shall cease, and the contract shall be automatically cancelled. In the case of partial impossibility, that part of the contract which is impossible shall be extinguished, and the same shall apply to temporary impossibility in continuing contracts, and in those two cases, it shall be permissible for the obligor to cancel the contract provided that the obliged is also aware."

It is seen that the article distinguishes between two kinds of performance impossibility, wholly and partially. In the first, the contract shall be cancelled by force of law. On the other hand, partially or temporarily, the contract can be cancelled by a decision of the latent in a condition to notify the property owner. Does this mean that the Defense order is considered as a force majeure?

In regard to the adopted definition of force majeure, it is considered as force majeure in case the lessor decides to cancel the contract. This is because the hire contract is used in continuing contract and the Civil Order is temporary with one condition which is to notify the owner of the property. This means that the obligation of paying the fare is not suspended according to the concept of force majeure.

Meanwhile, could it be considered as exceptional circumstances or not?

The Jordan legislator which defines exceptional circumstances in article No. 205 of Civil Code states that "If exceptional circumstances of a public nature which could not have been foreseen occur as a result of which the performance of the contractual obligation, even if not impossible, becomes oppressive for the obligor so as to threaten him with grave loss, it shall be permissible for the judge, in accordance with the circumstances and after weighing up the interests of each party, to reduce

\footnotetext{
4 The vocabulary of the Arabic does not distinguish between leasing (of real property) and hiring (of chattels). The words 'hire' and 'lease' and their derivative are used interchangeably throughout. Likewise, the word 'rent' is used irrespective of whether the subject matter of the contract is real property or chattel.
} 
the oppressive obligation to a reasonable level if justice so requires, and any agreement to the contrary shall be void."

Therefore, it is evident that cancellation option is missed in exceptional circumstances. Also, the contract of both parties does not enjoy making any decision. This is because the legislator gave the power to court where the judge can reduce the oppressive obligation to a reasonable level after weighing up both of the contract interests.

The Court of Appeal approved a decision to exempt tenants from paying the rent of commercial establishments for the period of the comprehensive coronavirus lockdown. The defence lawyers argued that the tenant is not in contravention of the terms of the lease contract, but the contract is suspended in the sense that the implementation of the obligation is impossible. The decision caused discontentment among landlords who said that they, too, had no fault in the shop closures. Many landlords vowed to fight this decision in court and sue any tenant who has not paid at least half the rent.

According to Jordanian law, the reciprocal obligations between the lessor and the lessee in the lease contract are for the lessor to provide the lessee a chance to obtain benefit from a leased property, and in return, the lessee pays the rent. However, the court finds that Jordan was and still is exposed to a global pandemic that has affected the implementation of contractual obligations. Therefore, the provisions of Defence Order No. 13 of 1992 have been activated to address the impact of the virus on the complete or partial inability of tenants to meet those obligations.

As this pandemic is an external event that has made the implementation of the contractual obligations impossible, and given that this is not due to the tenants' own fault, the court has decided to exempt them.

This means that Defense Order is an exceptional circumstance and the latent faces losses because of Curfew and closedown. Consequently, if a dispute arises between the latent and the owner for a suspended period of time, the latent can go to court. Here, the judge can reduce the fare amount to a reasonable level for the interest of both parties.

\section{Conclusion}

Consequently, by studying obligations of lessee and coronavirus legislation in Jordan, the study concluded that Defense Order issued in Jordan to face Corona Virus Disease 2019, by suspended ordinary laws of state. And this is the first applied to modified Defense Law 1993.

The main obligation of latent to pay fare is not suspended regarding to Defense Order No. 2, where he enjoys with two options. Firstly: he can cancel the leasing contract after notifying the property owner regarding to force majeure provisions. Secondly: he can refuge to court to reduce the fare amount because of Curfew regarding to exceptional circumstances provisions. It clearly that both force majeure and exceptional circumstances provisions may apply to Defense Orders. Finally, the study for the purpose of maintain the contracts and since Jordan is living in an exceptional period, the study recommends issuing a Defense Order specifying an 
exact percentage to be reduced. Also, in the absence of a Defense Order, the study of a friendly agreement should be recommended between the lessor and the tenant based on the reduced percentage.

Even if at the end, the concrete individual case and the recorded agreements are the deciding factor, in times of COVID-19 and the current pandemic phase, it is advisable to join forces with the contractual partner with the intention of a consensual, interests-balancing and yet problem-solving agreement. There is a common interest to keep the respective opposite party as a contractual partner. The loss of the premises and possibly of the operation is counterbalanced by the loss of rent and ultimately the re-letting, which is difficult to realise in the pandemic phase. Corresponding negotiations should therefore be well prepared on both sides, taking into account and referring to the possibilities discussed here.

The COIVD-19-induced crisis is an exceptional situation. An exceptional situation that must be dealt with. An exceptional situation that will most likely characterize and be characterized by legislation, courts and cases to be decided in the future. What is particularly interesting and noteworthy, and cannot be decided at the present, is to see how, in particular, the distribution of risk will be handled. However, in view of the uniqueness of the situation and taking into account the principle of good faith, it is conceivable that adjustments and novel, contemporary decisions will be made, and in some cases this is already apparent.

Acknowledgement The author is grateful to the Middle East University Amman, Jordan, for the financial support granted to defray the publication cost of this research article.

\section{References}

Jordan Civil Code No. 43 in the year 1976.

Jordan Constitution of 1952 amended in the year 2011.

The Jordan Defense Law Number 13 in the year 1992.

Publisher's Note Springer Nature remains neutral with regard to jurisdictional claims in published maps and institutional affiliations. 